Revista Eletrônica do Mestrado em Educação Ambienta1

Programa de Pós-Graduação em Educação Ambiental

\title{
Cartaz: Um contributo do Design para a formação do Educador Ambiental
}

\author{
Marco Antônio Costa ${ }^{1}$ \\ Instituto Politécnico de Bragança - Escola Superior de Educação \\ https://orcid.org/0000-0001-6761-7230
}

Luis Pires ${ }^{2}$

Associação Portuguesa de Educação Ambiental (ASPEA) https://orcid.org/0000-0002-8353-0079

Rui Mendonça ${ }^{3}$
Universidade do Porto - Faculdade de Belas Artes
https://orcid.org/0000-0003-3637-1770

Maria José Rodrigues ${ }^{4}$

Instituto Politécnico de Bragança - Escola Superior de Educação https://orcid.org/0000-0003-1029-149X

Resumo: Sendo a interdisciplinaridade científico-pedagógica uma das características basilares da Licenciatura em Educação Ambiental do Instituto Politécnico de Bragança, o seu plano curricular permite a integração das Artes Visuais e, em particular, o campo do Design de Comunicação Visual. Neste artigo pretende-se apresentar a conciliação entre o design e a promoção da literacia ambiental, evidenciando como a integração da metodologia projectual pode ser eficaz num

1 Mestre em Arte Multimédia pela Faculdade de Belas Artes da Universidade do Porto (FBAUP). Licenciado em Design de Comunicação pela FBAUP. Docente do Departamento de Artes Visuais da Escola Superior de Educação do Instituto Politécnico de Bragança. Colaborador do Instituto de Investigação em Arte, Design e Sociedade (I2ADS). email: marcocosta@ipb.pt.

2 Mestre em Educação Ambiental pela Escola Superior de Educação do Instituto Politécnico de Bragança. luis06pires@gmail.com

3 Doutor em Design pela Faculdade de Belas Artes da Universidade do Porto. Professor Auxiliar do Departamento de Design da Faculdade de Belas Artes da Universidade do Porto. Membro fundador do Instituto de Investigação em Design, Media e Cultura (ID+) . ruimendonca@fba.up.pt.

4 Doutora em Didática e Formação pela Universidade de Aveiro. Professora Adjunta do Departamento de Ciências da Natureza da Escola Superior de Educação do Instituto Politécnico de Bragança. Membro do Centro de Investigação em Educação Básica (CIEB). mrodrigues@ipb.pt

Rev. Eletrônica Mestr. Educ. Ambient. Rio Grande. v. 36, n. 3. Seção especial: V Congresso Internacional de Educação Ambiental dos Países e Comunidades de Língua Portuguesa. p. 319-335. Set/Dez. 2019.

E-ISSN 1517-1256 
contexto de formação de "não designers", demonstrando que a prática conceptualizadora, analítica e experimental promove educadores ambientais mais habilitados. Através da explanação das estratégias pedagógicas adotadas no contexto de uma proposta de trabalho no âmbito da unidade curricular referida acima, evidenciamos ainda, como o formato "cartaz" continua a ser um meio válido e funcional para a elaboração de mensagens síntese no espaço público, capazes de actuar sobre os comportamentos

Palavras-chave: Design. Cartaz. Educação Ambiental.

\section{Poster: A contribution from Design to the formation of the Environmental Educator}

Abstract: As scientific-pedagogical interdisciplinarity has been one of the basic characteristics of the Degree in Environmental Education of the Polytechnic Institute of Bragança, its curricular plan allows the integration of Visual Arts and, in particular, the field of Visual Communication Design. This paper aims to present the conciliation between design and the promotion of environmental literacy, showing how the integration of the project methodology can be effective in a context of formation of "non designers", demonstrating that the conceptualizing, analytical and experimental practice promotes more skilled environmental educators. Through the explanation of the pedagogical strategies adopted in the context of a work proposal within the unit of study referred to above, we also show how the "poster" format remains a valid and functional means for the elaboration of synthesis messages in the public space, capable of to act on the behaviors

Keywords: Design. Poster. Environmental Education.

\section{Cartel: Una contribución del Diseño a la formación del Educador Ambiental}

Resumen: Como la interdisciplinariedad científico-pedagógica es una de las características básicas del Grado en Educación Ambiental del Instituto Politécnico de Braganza, su plan curricular permite la integración de las Artes Visuales y, en particular, el campo del Diseño de la Comunicación Visual. Este documento tiene como objetivo presentar la conciliación entre el diseño y la promoción de la alfabetización ambiental, mostrando cómo la integración de la metodología del proyecto puede ser efectiva en un contexto de formación de "no diseñadores", demostrando que la práctica conceptual, analítica y experimental promueve educadores ambientales más hábiles. Mediante la explicación de las estrategias pedagógicas adoptadas en el contexto de una propuesta de trabajo dentro de la unidad curricular mencionada anteriormente, también mostramos cómo el formato de "póster" sigue siendo un medio válido y funcional para la elaboración de mensajes de síntesis en el espacio público, capaz de actuar sobre los comportamientos

Palabras clave: Diseño. Cartel. Educación Ambiental.

\section{A LICENCIATURA EM EDUCAÇÃO AMBIENTAL DA ESEB}

A Escola Superior de Educação (ESEB) do Instituto Politécnico de Bragança (IPB) (Portugal) oferece, desde 2005, uma formação superior no campo da Educação Ambiental (EA). Nas origens desta formação, encontramos uma primeira licenciatura bietápica que, à data, se designava Educação Ambiental e Animação Cultural. Na origem deste curso esteve presente uma noção bastante alargada da Educação Ambiental, associada a uma vertente lúdica por meio da sua aplicação em actividades junto da comunidade.

Rev. Eletrônica Mestr. Educ. Ambient. Rio Grande. v. 36, n. 3. Seção especial: V Congresso Internacional de Educação Ambiental dos Países e Comunidades de Língua Portuguesa. p. 319-335. Set/Dez. 2019.

E-ISSN 1517-1256 
Derivado da necessidade de adequação da licenciatura ao "processo de bolonha", no ano de 2006, o curso passou a designar-se somente por Educação Ambiental. No entanto, a sua estrutura de banda larga manteve-se, continuando a incluir áreas de conhecimento diversas, de modo que o perfil de formação dos alunos se adequasse ao próprio espectro alargado da EA, tal como se encontra em instituições públicas e privadas tão diversas como autarquias, empresas de turismo, desporto, associações, parques biológicos, centros educativos, culturais, etc. Como grande objectivo, pretendeu-se formar profissionais aptos a criar acções de promoção da cidadania, da literacia ambiental e do património natural e cultural, numa perspectiva de valorização e protecção dos recursos e que contribuam para a desejada qualidade de vida, tanto individual como colectiva.

Em 2015, de modo a dar resposta às necessidades de avaliação externa para acreditação da qualidade da formação ${ }^{6}$, procedeu-se a nova reformulação curricular na qual se reforçaram as áreas nucleares da EA. No entanto, manteve-se a sua filosofia transversal e interdisciplinar na qual, encontramos áreas cientifico-pedagógicas ligadas às Ciências da Natureza , Ciências da Educação, Ciências Sociais, Gestão e Administração, Língua e Literatura Portuguesa, Línguas Estrangeiras, Psicologia e Artes Visuais. Na base desta estrutura está a consciência da importância dos futuros educadores ambientais terem no seu plano de formação, a integração diversificada de áreas científicas. Esta diversidade permite que as várias áreas não concorram isoladas por si só como bases necessárias ao futuro educador ambiental, mas antes, tendam a cruzar os temas da EA nos seus territórios disciplinares, de modo que o pensamento conexo dos conhecimentos diversos permitam um entendimento mais contextualizado dos temas.

No cerne deste modelo estão estratégias de ensino-aprendizagem que permitem retirar das áreas satélite, certos conteúdos que favorecem a formação nuclear do educador ambiental. Igualmente, está implícita a convicção de que a literacia ambiental do educador tem que ser apreendida afastando-se dos métodos de resposta pré-definida e fechada nela própria, aproximando-se da reflexão sobre os temas, através da abertura aos diferentes

5 O designado "processo de bolonha" foi um sistema de reforma do ensino superior na Europa, da qual fazem parte, neste momento, 47 países (incluindo Portugal) e que instituiu o Espaço Europeu de Ensino Superior (EEES). O seu principal objectivo foi o de introduzir meios de uniformização da gestão do ensino, por forma a facilitar e aumentar sistemas de cooperação, mobilidade e de creditação entre as instituições de ensino superior europeias.

6 Em Portugal, institui-se em 2007 através do Decreto-Lei no 369/2007, de 5 de novembro uma fundação de direito privado designada Agência de Avaliação e Acreditação do Ensino Superior (A3ES). A sua principal missão é garantir a qualidade das instituições de ensino superior e dos seus ciclos de estudos, através da definição de padrões de qualidade que determinam processos de avaliação com vista a acreditação e em consequência, a garantia da qualidade no cumprimento dos requisitos legais do seu reconhecimento (www.a3es.pt). A licenciatura em Educação Ambiental da Escola Superior de Educação do Instituto Politécnico de Bragança obteve em 2015, acreditação plena (6 anos).

Rev. Eletrônica Mestr. Educ. Ambient. Rio Grande. v. 36, n. 3. Seção especial: V Congresso Internacional de Educação Ambiental dos Países e Comunidades de Língua Portuguesa. p. 319-335. Set/Dez. 2019.

E-ISSN 1517-1256 
contextos das áreas disciplinares. Por este modo, entende-se que o futuro educador poderá estar mais apto a fornecer uma melhor literacia ambiental ao cidadão comum, que tem em si naturezas culturais diversificadas, por usar os mesmos métodos com os quais foi ele próprio instruído.

\section{A Literacia Ambiental}

Muito embora as questões ambientais sejam fortemente debatidas, parece haver uma ideia genérica de ausência de resultados práticos significativos. Deste modo, é cada vez mais importante e necessário promover e desenvolver a literacia ambiental. Desde a década de 70 que a educação ambiental tem ganho relevo. O apoio crescente entre os educadores ambientais no sentido de desenvolver indivíduos responsáveis pelos seus comportamentos sobre o meio ambiente, passou a ser um dos principais objectivos da educação ambiental. Em 1972, na Conferência das Nações Unidas para o Ambiente Humano, que decorreu em Estocolmo, a educação foi entendida como a principal forma de encontrar soluções para os problemas ambientais. Em 1975, no decorrer de um encontro promovido pela UNESCO, foi adoptada a Carta de Belgrado na qual ficou estabelecida a finalidade da educação ambiental: formar uma população mundial consciente e preocupada com o ambiente e com os seus problemas, uma população que tenha os conhecimentos, as competências, o estado de espírito, as motivações e o sentido de compromisso que the permitam trabalhar individual e colectivamente na resolução das dificuldades atuais, e impedir que elas se apresentem de novo. Igualmente, a conferência intergovernamental sobre educação ambiental, ocorrida em Tbilisi no ano de 1977, organizada pela UNESCO, definiu a sua estrutura, princípios e linhas de orientação, deixando claro que o seu objectivo destinava-se a promover a literacia ambiental nos cidadãos de modo que estes desenvolvam práticas respeitadoras do ambiente. Assim, o desenvolvimento de uma cidadania ambientalmente literata é um importante propósito da educação ambiental, sendo a literacia ambiental um requisito indispensável para que a sociedade mantenha e melhore a qualidade ambiental. A literacia ambiental, enquanto capacidade de compreender e interpretar o equilibrio relativo dos sistemas ambientais, deve incluir, além do conhecimento e compreensão dos problemas do meio ambiente, formas de por em prática esses conhecimentos na adopção de decisões em contextos ambientais. Esta posição, permite adoptar as acções apropriadas para manter, restaurar ou melhorar a saúde desses 
mesmos sistemas. Vários autores defendem esta perspectiva de proximidade contextual para um domínio da área da educação ambiental. Ainda na década de 70, Arthur Maurice Lucas, considerava que o contexto para o desenvolvimento da literacia ambiental teria de ser o próprio meio ambiente através do envolvimento dos alunos na implementação de medidas para a sua protecção, ou seja, a educação ambiental deverá basear-se em aprender no ambiente e para o ambiente. Na mesma linha de raciocínio, o professor e investigador Helder Spínola, num artigo dedicado à literacia ambiental em 2016, conclui que "todas as evidências nos empurram para a necessidade de adoptar uma nova estratégia de ensino e aprendizagem no contexto da promoção da literacia ambiental, obrigando a educação ambiental a fazer-se com a escola mas fora dela, no meio do contexto social dos jovens, no coração das suas famílias e em simultâneo com o pulsar da sociedade e das comunidades locais". Em faixas etárias mais jovens, para além do contacto directo com a natureza, sabese que um adulto que seja visto como um modelo na mediação entre o problema ambiental e a criança, contribui para o aumento da literacia.

Assim, é tácito que o desenvolvimento da literacia ambiental está directamente ligada com as estratégias pedagógicas. Para que a formação do educador ambiental não esbarre no ensino formal de carácter abstractizante, centrado na exposição do professor sem relevo dos contextos próprios da realidade do ambiente, alguns autores como Hélder Spínola defendem a "importância dos factores culturais e socioeconómicos[...] feito à luz dos modelos de aprendizagem baseados no construtivismo social". Grosso modo, a importância desta perspectiva advêm do facto dos contextos reais de aprendizagem terem que ser mais e melhor adoptados, afastando-se da centralidade do modelo escolar que, em grande medida, cria barreiras com os contextos reais dos problemas ambientais, que são abordados na própria escola. Ultrapassar a prisão do contexto formal da sala de aula, do ensino abstracto centrado no modelo expositivo do professor com pouca ou nenhum ligação aos contextos reais dos problemas ambientais, é uma necessidade efectiva na formação do educador para uma melhor promoção da literacia ambiental. A proximidade da formação em contexto, por onde o aluno consegue identificar características, factos e variáveis relacionados com a experiência directa do meio social, económico e cultural, consegue criar relações holísticas que lhe fornecem conhecimento contextual, permitindolhe ter uma percepção mais conexa da sua área e ficando melhor preparado para educar ambientalmente.

Rev. Eletrônica Mestr. Educ. Ambient. Rio Grande. v. 36, n. 3. Seção especial: V Congresso Internacional de Educação Ambiental dos Países e Comunidades de Língua Portuguesa. p. 319-335. Set/Dez. 2019. E-ISSN 1517-1256 


\section{O Contributo do Design}

Como dissemos acima, a interdisciplinaridade presente na LEA beneficia do contributo das Artes Visuais, pela integração de uma unidade curricular (UC) de Design de Comunicação Visual (DCV). Esta UC tem por objectivo principal, fornecer aos alunos conhecimentos teóricos e de prática projectual que sejam favoráveis à resolução de problemas de comunicação numa vertente gráfica. De forma mais pragmática e operativa, pretende-se também que o campo do design de comunicação contribua com conceitos, metodologias e ferramentas para a elaboração de produtos gráficos tanto de divulgação (jornais, boletins, folhetos, brochuras,) como de sensibilização / consciencialização e alerta para campanhas ambientais (cartazes, outdoors).

Em todo o caso, tem sido estratégia docente desta UC, promover a formação do educador ambiental numa base construtivista. Por meio de propostas de trabalho que exigem do aluno (futuro educador) contextualizar realidades concretas da EA, parte-se para a necessidade de relaciona-los com os objectivos das propostas no âmbito do Design.

Uma das valências do Design é lidar com paradoxos. Para tal, usa estratégias reflexivas através de um pensamento dinâmico que dialoga em tempo real com a situação, procurando a forma enquanto se trabalha sobre a própria forma. Os contextos imprevisíveis, complexos, indeterminados, conflituosos e instáveis, são o campo de trabalho do Design, que origina uma procura / pesquisa modelada sobre sistemas especializados, ultrapassando a especialização de comportamentos modelados. Ao repensar processos, esta reflexão sobre a acção, fornece meios para soluções não estereotipadas e portanto, possivelmente, inovadoras.

Se o o conhecimento é construído por meio de interações entre o individuo e o meio, o mesmo se pode dizer da prática do design. O conhecimento em Design provêm da acção, sendo que esta nunca é independente do individuo. Projecta-se por pessoas para pessoas e como tal, o Design também é uma atitude para o processo de aprendizagem. Deste modo, o contributo do Design para o educador ambiental, advêm de o colocar sobre condições não estáveis, imprevistas e conflituosas dos próprios problemas ambientais e que o desafiam a reflectir constantemente, por onde aprende aprendendo, tornando-o mais literato ambientalmente.

Historicamente, desde que a noção de Design se afirmou a partir de finais do século XIX, foi crescendo o papel activo dos seus autores ao nível social e cultural. Queremos 
dizer que o designer foi conquistando o seu terreno sócio-cultural por intermédio da sua actividade intelectual. Como alguém especialista na conceptualização e planeamento, mais do que na necessidade de dominar por si só a produção do artefacto, a sua afirmação foi crescendo por intermédio da reflexão necessária ao próprio desenvolvimento do design. $\mathrm{Ou}$ seja, pelo facto do design ser em si uma actividade com um forte pendor analítico e reflexivo, permite ao designer ser consciente da sua condição de agente de mudança. Este papel interventivo do designer da-se por duas vias. Por um lado, a posição do designer enquanto profissional e um meio necessário de conceptualização e planeamento da mensagem em favor das ideologias, não necessariamente suas, e por outro, a condição do designer ser ele próprio um cidadão consciente dos seus ideais político-social e aliar a sua capacidade de criação de conteúdos para se assumir como autor dos seus materiais gráficos de intervenção.

No entanto, foi só a partir da década de 60 do século XX que se afirmou uma maior consciência social no design. Esta tomada de consciência foi activada numa primeira fase, por alguns teóricos como Buckminster Fuller e Victor Papanek que ao estarem ligados ao ensino, puderam influenciar algumas gerações de novos arquitectos e designers que começaram a aplicar uma maior responsabilidade social ao seu trabalho criativo e projectual através da ideia de "economia de meios". Desde a segunda década do século XX que se vinha a formar uma nova ideologia pela qual se aceitou a industrialização, vendo-a como um fato consumado da era moderna. Para estes arquitectos e designers, a rejeição do historicismo conduzia à celebração do progresso industrial como forma de melhorar o design democrático. Mas após a $2^{\mathrm{a}}$ Guerra mundial e de forma mais específica no Design Gráfico, esta posição ideológica dos modernistas foi-se tornando cada vez mais dogmática. Estabeleceram-se normas rigorosas sobre o design e tipografia por forma a minimizar o desperdício e melhorar a leitura, através do uso de grelhas, evitando composições simétricas, utilizando apenas tipos de letra sans serif, em colunas de texto alinhadas à esquerda, privilegiando a fotografia sobre a ilustração.

Como reacção a este movimento modernista internacional, que privilegiou a racionalidade e funcionalismo no Design, os movimentos de contra cultura e underground, de intervenção cívica, política e artística, principalmente estabelecidos na Califórnia, a partir dos anos 60, admitiam novas linguagens baseadas num espirito muito mais expressivo, plástico e pessoal. O próprio movimento Pop, trouxe consigo a cultura de massas, que deu ao Design a possibilidade de absorver influências quotidianas 
transformando-os em ícones de leitura rápida. Neste contexto, o próprio design foi-se alterando de modo a incluir nas suas práticas, mensagens com um carácter mais interventivo, alternativo e político.

É a partir desta década que, no campo mais especifico dos movimentos e das instituições ligadas à ecologia e ao "movimento verde", encontramos igualmente uma consciência cada vez mais activa da intervenção social, que foi evoluindo para uma cultura ligada aos movimentos alternativos dos anos 70. Genericamente, este ganho de consciência sobre o ambiente e a ecologia, acabou por despoletar uma atitude autocrítica em relação aos estilos de vida, principalmente ocidentais, assim como o sentido de responsabilidade sobre a sociedade e sobre o próprio planeta no que respeita à exploração desenfreada dos seus recursos naturais. Não foi por acaso que em 1971 se criou através de um grupo de activistas ambientais o movimento Greenpeace, um das organizações não governamentais mais bem sucedidos no que se refere à expansão dos seus ideais ao nível global. E mesmo com o abalo em 1973 da crise do petróleo, este só reforçou a necessidade de se criar meios mais eficazes de valorização social em detrimento do puramente económico.

Por outro lado, também várias corporações empresariais, viram nesta tomada de consciência ambiental, uma forma de promoverem uma certa filosofia de mercado no sentido de definirem um posicionamento dos seus produtos associados a causas sociais e ambientais. Um dos exemplos mais conhecidos é o caso da marca Benetton que, por meio de estratégias de marketing, produziu várias campanhas publicitárias nas quais usava o recurso a mensagens de alerta, para criar empatias entre o tipo de público consumidor dos seus produtos e as causas para as quais apelava. Igualmente como exploração comercial das empresas, principalmente das marcas globais, começaram a ser desenvolvidas estratégias comunicativas de associação de conceitos como "amiga do ambiente", "produto verde" ou "sustentabilidade" por forma a criar mais valias comerciais dos produtos criados com recurso a técnicas de reciclagem, a matérias biodegradáveis, bem como a políticas de redução de meios de produção, embalamento e transporte.

O Pós-Modernismo, deu origem a linguagens muito mais personalizadas que abriram campos ao Design de forma a explorar o trabalho autoral, como algo legítimo no processo de Design. O Designer tinha a partir de agora uma vantagem do seu lado: as suas convicções, estilos, ideais, poderiam entrar formalmente no produto de Design, longe do carácter, muitas das vezes insípido que o modernismo tinha trazido. Esta mudança veio criar igualmente uma responsabilidade ética na actividade do Design, que o legitimou para Educação Ambiental dos Países e Comunidades de Língua Portuguesa. p. 319-335. Set/Dez. 2019. 
a forma como poderia ou não, aceitar trabalhos que pudessem ou não, ir contra os seus ideais.

Muito embora esta condição possa, muitas das vezes, ser uma utopia, o que é facto é que a possibilidade do Designer fazer escolhas por si e assumi-las de forma pessoal, permitem-lhe que as imagens por ele produzidas, sejam parte do seu discurso politico. Campanhas anti-racismo, anti-nacionalismo, de luta pelos direitos do homem, pelos direitos dos animais, consciencialização ambiental, contra a fome, anti-violência, etc, materializadas através do Design gráfico, permitem uma voz sempre activa e presente no meio social, pelas causas em que acredita.

\section{O Cartaz Social e Político}

O que se designa como propaganda política, protesto, agitação e alerta existe, a bem dizer, desde que o homem se consciencializou de que vivia em sociedades organizadas. Ao longo dos tempos a forma de expor publicamente essas ideias teve um aliado bastante forte na potencialidade da comunicação gráfica e no aproveitamento do espaço público. $\mathrm{O}$ formato cartaz, foi, pelo menos até meados dos anos 90, uma arma de comunicação gráfica bastante activa no modo de divulgação pública de mensagens. O cartaz tem, por natureza, um poder que se materializa em mensagens visuais breves, únicas, fortes, instantâneas e concentradas. Sejam elas de carácter comercial, cultural ou políticas, o cartaz fala de cima de um palco, dando a "voz" de forma projectada e segura. Não é de estranhar assim que desde os primeiros cartazes a partir de meados do século XIX, se entendesse a importância do grande formato, das cores vivas e das ilustrações sedutoras. Conseguir combinar a imagem com um texto curto, que permite uma leitura rápida e a percepção clara da mensagem realçava a importância da dimensão psicológica da sedução e do impacto emocional.

Muita da história do design gráfico é coincidente com a história do cartaz, sendo ainda hoje considerado um formato "heroico". Pela sua historicidade associada ao desenvolvimento de estilos visuais e de afirmação artística por parte dos seus autores, a sua reputação e reconhecimento como produto cultural e patrimonial, foi crescendo ao longo de todo o século XX, sendo muitas vezes o barómetro de análise do papel social da comunicação visual. Assim, acreditamos que este estatuto não mudará, enquanto a nossa preponderância visual na assimilação das mensagens assim continuar.

Rev. Eletrônica Mestr. Educ. Ambient. Rio Grande. v. 36, n. 3. Seção especial: V Congresso Internacional de Educação Ambiental dos Países e Comunidades de Língua Portuguesa. p. 319-335. Set/Dez. 2019. 
Mas se a televisão a partir dos anos 60, enquanto meio de comunicação de massas ultrapassou o cartaz, pelo menos na sua vertente comercial, os nichos da divulgação cultural e política não abandonaram tão rapidamente o meio impresso. O cartaz, tornou-se num meio mais propício para mensagens de contexto mais focado podendo chegar a públicos mais específicos e a sua vertente mais artística e militante foi florescendo durante toda a década de 70. A partir dos anos 80, as acções "verdes" tornaram-se mais concretas no sentido de haver cada vez mais campanhas de agitação através dos média, assim como a cobertura destes em relação às próprias actividades pró-ambientais. O cartaz acompanhou estas necessidades sociais e políticas actuando mais directamente em campanhas, por ativistas e artistas da comunidade que, ao colocar no espaço público os seus cartazes, assumiam uma atitude subversiva sobre a posição de autoridade e domínio da publicidade.

Considerando que nos anos 80 a solidariedade global ainda era vista como algo distante, a internet dos anos 90 tornou possível uma comunicação espontânea de um-paraum em todo o mundo. Subitamente, o mundo parece ter encolhido drasticamente através da instantaneidade da acessibilidade e disseminação de informações pela rede, criando uma noção de globalidade e omnipresença.

Mas se o cartaz (impresso) deixou de ser considerado como um paradigma da comunicação em espaço público, não deixou de ter as suas armas funcionais quando o mesmo se apresenta se o colocarmos no campo das imagens. A grande mudança verificada foi a apropriação do formato cartaz para um uso mais individualizado e menos empresarial. Os sistemas de edição, impressão e reprodução democratizados pelas fotocopiadoras, computadores, softwares de edição de imagem e impressoras caseiras, deram a possibilidade ao comum dos cidadãos, de ter ao seu dispor várias técnicas das artes gráficas, anteriormente só dispostas para uso dos especialistas e profissionais. Com a globalização informativa digital, a veiculação de mensagens criou um novo paradigma social. A possibilidade de cada pessoa ter o seu canal próprio de informação pessoal, permitiu criar oportunidades de expressão que de outra forma não teria qualquer repercussão. E se o design e as imagens por ele criadas podem ainda fazer a diferença, será junto daqueles que mais afastados estão dos grandes centros económico-sociais desenvolvidos. Junto daqueles que mais dificuldade têm em dar voz às suas causas, os conflitos da globalização só serão sentidos como próximos e reais quanto mais as mensagens locais politizadas sejam expandidas na rede. Deste modo, o poder do design gráfico para cruzar fronteiras e unir culturas em solidariedade nunca foi mais pertinente. 


\section{A PROPOSTA}

Partimos da noção que é de "extrema importância sensibilizar, (in)formar e consciencializar toda a população da consequência das suas atitudes no meio ambiente, de modo a verificarem-se alterações nos procedimentos atuais" (PIRES, 2016, p.10). Mas, o acto de informar não pode ser separado do modo de comunicar dessa informação. Daí que entendemos que a abordagem pelo design de comunicação de um problema ambiental, pode ser um meio eficaz na mudança de comportamento de um certo grupo de pessoas causadoras desse problema. Por ser uma actividade focada na criação de estratégias de comunicação visual e domínio dos elementos visuais para o melhor efeito comunicativo, ela fornece mais possibilidades de assertividade da mensagem e em consequência, de consciencialização sobre o problema.

A necessidade de elaborar uma mensagem visual de alerta / consciencialização, não pode ir contra o efeito dessa mesma mensagem. Queremos dizer que a eficácia comunicativa para a mudança do comportamento tem tendência a esbarrar em retóricas comunicativas que se tornam efềmeras seja pela previsibilidade do seu conteúdo, seja pela redundância informativa, seja pela psicologia inversa resultante de uma má literacia visual. No contexto académico da UC de DCV, é proposta a elaboração de um cartaz com o objectivo de alertar para um problema ambiental do interesse particular do estudante. $\mathrm{O}$ principal objectivo desta proposta é poder dar ao estudante ferramentas metodológicas e projectuais que o levem a entender e dominar, os modos de comunicar visualmente um dado problema ambiental e poder encontrar o foco de actuação da mensagem, para a mudança comportamental humana. O sentido funcional de um cartaz político / alerta / consciencialização / agitação, consegue ser tanto mais eficaz, quanto mais criar no receptor um sentimento de intranquilidade por meio da consciencialização de um problema possível para ele próprio.

Numa primeira abordagem, pede-se ao estudante que elabore, de forma intuitiva, uma mensagem visual que possa comunicar um problema ambiental e contribua para a mudança de comportamento dos causadores desse problema. Sem fazer referência a métodos ou estratégias de actuação do design, queremos apenas avaliar como a o aluno desenvolve uma possível solução a partir do seu conhecimento inato, empírico e intuitivo sobre elementos visuais de comunicação. Para um melhor entendimento das fragilidades 
comunicativas mais comuns que são apresentadas neste contexto, escolhemos três projectos de três alunos que se apresentam abaixo:

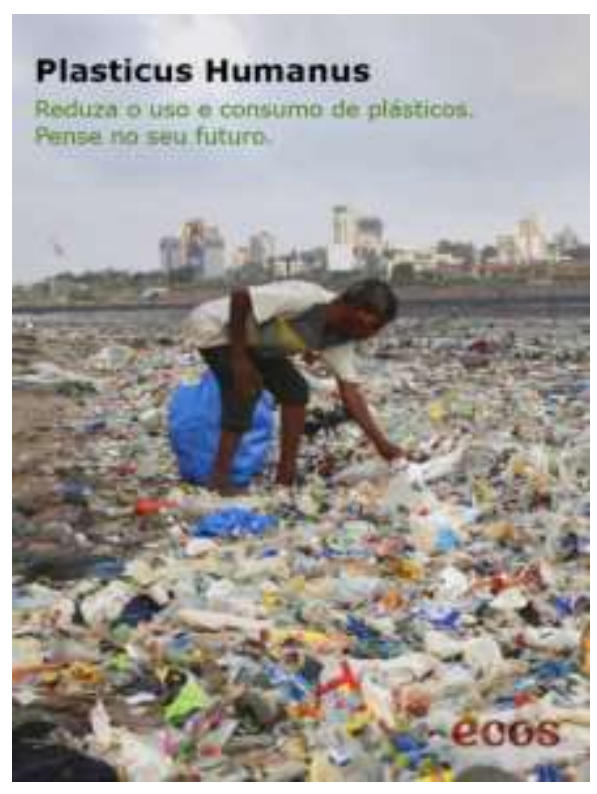

Fig. 1 - Primeiro Cartaz. Aluno A

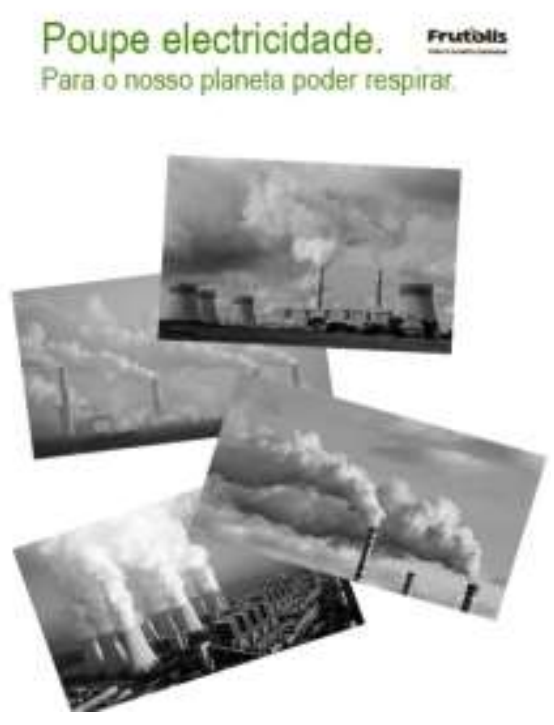

Fig. 2 - Primeiro Cartaz. Aluno B

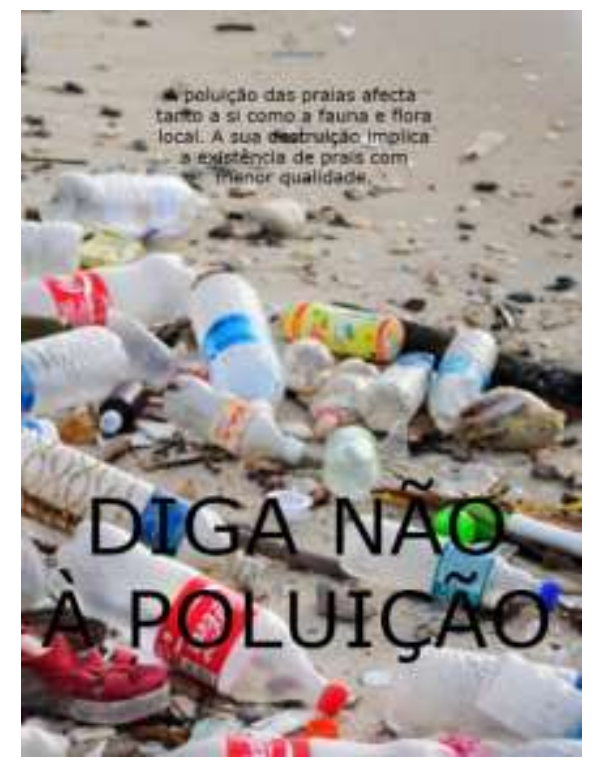

Fig. 3 - Primeiro Cartaz. Aluno C.

Regra geral, é sintomático os alunos elaborarem o cartaz dando ênfase ao problema. Usam tanto os elementos verbais como os imagéticos de forma a informar sobre o problema em concreto. A existência de redundância informativa (Fig. 1 e Fig. 3), onde a fotografia e o texto focam a mesma informação, não beneficia a eficácia da mensagem.

Rev. Eletrônica Mestr. Educ. Ambient. Rio Grande. v. 36, n. 3. Seção especial: V Congresso Internacional de Educação Ambiental dos Países e Comunidades de Língua Portuguesa. p. 319-335. Set/Dez. 2019. 
Num outro nível, os alunos têm a tendência para usar textos explicativos, de certo modo longos no que diz respeito à sua aplicação no formato cartaz (Fig. 3). Evidencia-se que os alunos têm pouca percepção da necessidade da mensagem ser o mais directa e focada possível, dado a genérica aplicação que se faz do cartaz que é, estar exposto em locais públicos e de passagem, pouco propícios à disponibilidade de tempo para leitura por parte do receptor. A profusão de elementos, é outra das características presentes (Fig. 2). Esta opção dá-se pelo facto do aluno assumir que ao colocar mais elementos informativos obterá, por relação directa, mais hipótese de explicar ao receptor o problema em concreto. O erro nesta opção dá-se, por um lado, pela redundância informativa, e por outro porque a profusão, enquanto "uma distribuição complexa, variada em escala, direcção e cor" (MENDONÇA, 2007, p. 290) torna-se uma desvantagem se não for uma "atitude articulada tanto quantitativa e/ou qualitativamente" (MENDONÇA, 2007, p.290).

Em todos estes casos, a mensagem torna-se retórica e portanto literal e previsível. A actuação dos elementos enquanto imagem, não ultrapassam uma esteriotipagem do seu conteúdo o que leva apenas à demonstração das evidências comuns e não o foco nos pormenores do problema.

\section{O MÉTODO}

De modo a ultrapassar estas inconveniências formais e conceptuais para elaboração de um cartaz de consciencialização, colocamos em prática uma metodologia de trabalho que se divide em três momentos. Em primeiro lugar, o aluno tem que justificar o problema ambiental. Esta necessidade obriga o estudante a perceber, desde o contexto mais local, o porquê dos factos constituirem um problema ambiental. Por este meio, o aluno tem que fazer um levantamento de dados que permitam contextualizar uma certa problemática onde as variáveis naturais, sociais e culturais são definidas de modo que o problema ambiental possa ser compreendido por terceiros. Implicitamente, exige-se ao aluno que o levantamento destes dados seja feito em campo e não de forma abstracta em contexto formal em sala de aula.

Num segundo momento, o aluno deve caracterizar o (um) grupo social que seja identificado como o causador mais directo do problema definido anteriormente. Esta especificidade de análise permite que o aluno compreende em que contexto sócio-culturais, certos comportamentos criam o problema ambiental e contribuem para a sua perpetuação. 
A exigência desta especificidade acaba por focar o público-alvo a que se destinará a mensagem do cartaz. Novamente, os dados desta análise são construidos na proximidade com o meio social em estudo.

Quando o aluno consegue clarificar este contexto comportamental, pode evoluir para o terceiro momento da metodologia que se orienta na compreensão de como os causadores do problema podem, eles próprios, sofrer com o problema causado. O que se pretende nesta fase, é que o aluno consiga identificar em que contexto, os causadores acabam por fazer parte da cadeia de prejuízo. A compreensão desse facto, exige que o contexto seja o mais específico possível, de modo a evitar generalizações e retóricas sobre os comportamentos sócio-culturais.

Como dissemos anteriormente, em Design, é importante encontrar a forma enquanto se trabalha sobre a própria forma e sendo que em design, esta estabelece uma forte ligação à dimensão conceptual, estes três momentos são desenvolvidos em paralelo com pesquisa formal, de modo que os alunos possam ter um pensamento visual sobre as soluções que vão sendo definidas. Da forma mais resumida, o que tentamos definir por este método são as linhas programáticas com as quais o projecto de design se formalizará na construção de uma mensagem visual. Retiram-se deste processo noções que permitem fazer escolhas de elementos formais que possam conter em si, conotações com as quais se elaboram significados. Textos e imagens só podem ser eficazes num processo de comunicação quando o contexto é compreensível para o receptor.

$\mathrm{Na}$ especificidade de uma mensagem de alerta / consciencialização, pretende-se que haja um sentido narrativo na imagem global do cartaz. O conjunto do texto e da imagem, permite criar conotações que expandem o efeito sígnico isolado de cada uma das partes. A estratégia gráfica (composição dos elementos formais, exploração plástica dos mesmos e conformidade comunicativa de todo o conjunto gráfico) é na maior partes das vezes explorada a partir de imagens fortemente icónicas, em que a presença do género fotográfico providencia uma legibilidade bastante grande no que toca à informação dos referentes. $\mathrm{O}$ acompanhamento de uma mensagem verbal de carácter incisivo, inquiridor e emocional, é formalizado por tipografias que criam contrastes visuais fortes com a imagem e compostas em zonas de fácil concentração do olhar.

Tenta-se assim criar uma imagem gráfica pela qual o receptor identifica um problema, pela consciencialização de que ele próprio, é parte causadora do mesmo. A viragem sobre o apex da informação, dá-se pela forma como a mensagem cria o sentimento 
de intranquilidade tocando o individuo na sua "ferida". Deste modo, a mensagem torna-se mais eficaz por transformar o problema geral num problema pessoal. As imagens seguintes representam os cartazes finais dos mesmos estudantes, autores dos cartazes acima referidos.

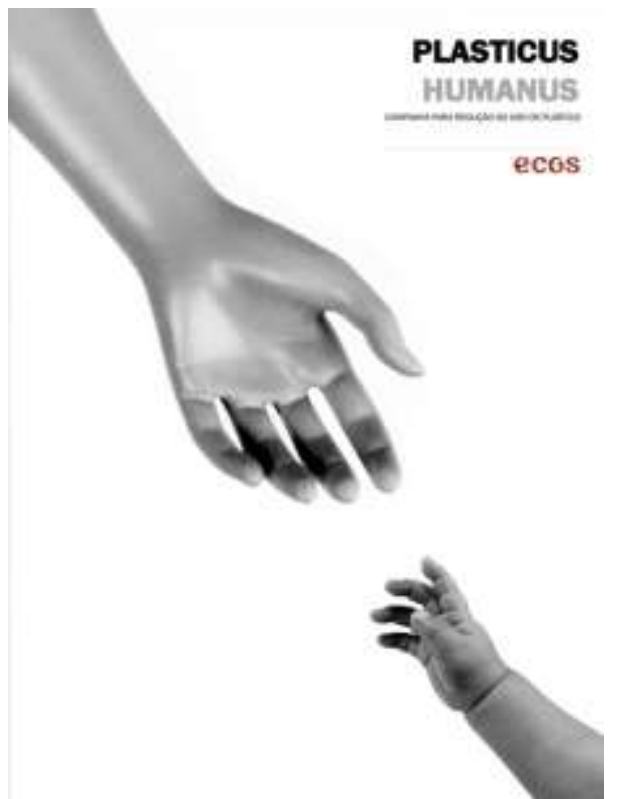

Fig. 4 - Cartaz Final. Aluno A

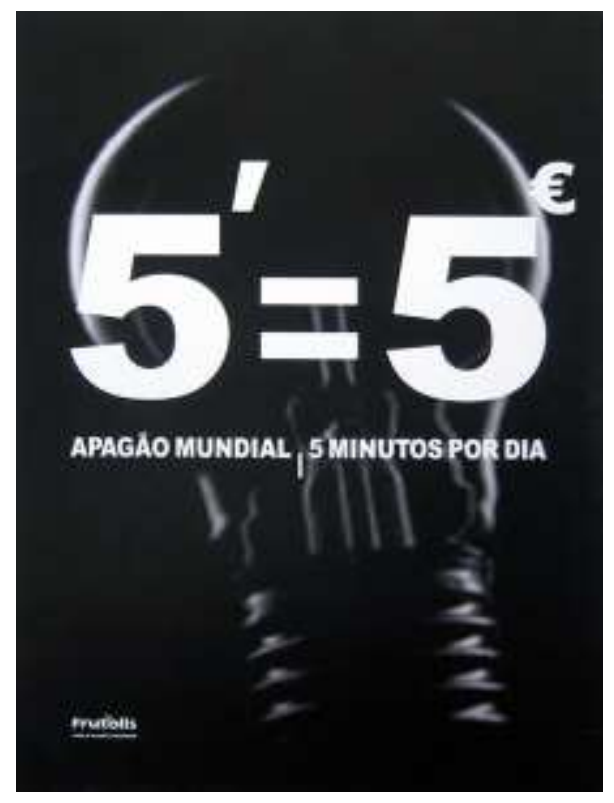

Fig. 5 - Cartaz Final. Aluno B.

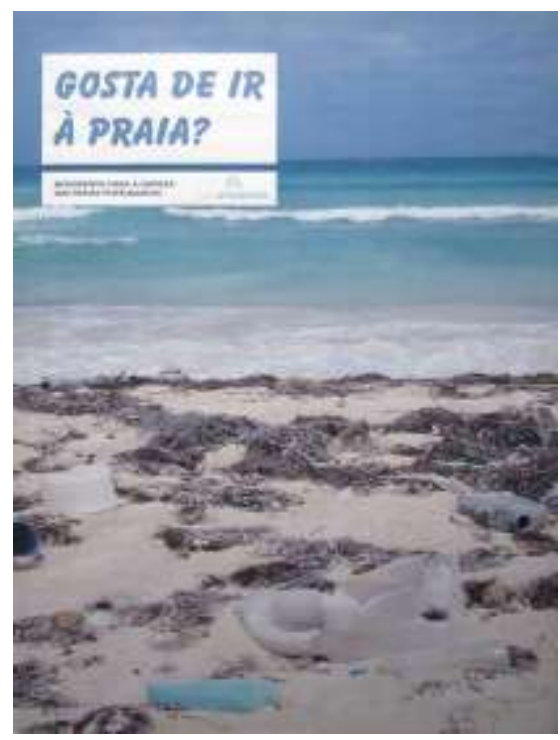

Fig. 6 - Cartaz Final. Aluno C.

Rev. Eletrônica Mestr. Educ. Ambient. Rio Grande. v. 36, n. 3. Seção especial: V Congresso Internacional de Educação Ambiental dos Países e Comunidades de Língua Portuguesa. p. 319-335. Set/Dez. 2019. 


\section{CONCLUINDO}

Num processo de design, a contextualização das acções sobre o projecto, é uma necessidade constante. $\mathrm{O}$ designer aprende por recriar ambientes que the permite expandir a sua aprendizagem para fora do âmbito estritamente académico. Prever o comportamento do seu objecto em contacto com um certo público exige entender os contextos particulares do publico que terá contacto prático com esse objecto.

Se o educador, é um elemento fundamental para a literacia ambiental, entendemos que deve receber a sua formação orientada pela própria necessidade de ser literato na área. O contributo do design para a formação do educador ambiental é dado pela forma como a metodologia projectual o pode tronar mais apto à resolução de um problema, pois a aprendizagem pelo design requer estratégias pedagógicas derivadas do modelo construtivista que exige uma proximidade com os fenómenos em si, para um melhor entendimento do conhecimento.

\section{REFERÊNCIAS}

COSTA, Marco António; MENDONÇA, Rui. O cartaz e o teatro. Um modelo de análise para revelação de traços identitários. Livro de Actas UD14 $-1^{\circ}$ Encontro Ibérico de Doutoramentos em Design $/ 3^{\circ}$ Encontro Nacional de Doutoramentos em Design, Universidade de Aveiro - Departamento de Comunicação e Arte. Aveiro, p. 148-153, 2015.

DISINGER, John; ROTH, Charles. Environmental Education research news. The Environmentalist, v.12, p.165-168, 1992.

ENEL, Françoise. L’Afiche - Fonctions, Langage Rethorique. Paris. Mame, 1971.

FROST, Malcom; LEWIS, Angharad; WINTERBURN, Aidan. Street Talk. The rise and fall of the Poster. Victoria. The Images Publishing Group, 2006.

GALlO, Max. The Poster in History. New York. W. W. Norton \& Company, 2001

GLASER, Milton; ILIC, Mirko. The Design of Dissent: Socially and Politically Driven Graphics. Gloucester. Rockport Publishers, 2005.

HUNGERFORD, Harold; VOLK, Trudi. Changing learner behavior through environmental education. The Journal of Environmental Education, v.21 (3), p. 8-22, 1990.

LUCAS, Arthur Maurice. Environment and environmental education: Conceptual issues and curriculum implications. Melbourne, VIC: Australian International Press and

Rev. Eletrônica Mestr. Educ. Ambient. Rio Grande. v. 36, n. 3. Seção especial: V Congresso Internacional de Educação Ambiental dos Países e Comunidades de Língua Portuguesa. p. 319-335. Set/Dez. 2019. 
Publications, 1979.

McQUISTON, Liz. Graphic Agitation: Social and Political Graphics since the Sixties. New York. Phaidon, 2000.

McQUISTON, Liz. Graphic Agitation 2: Social and Political Graphics in the Digital Age. New York. Phaidon, 2004.

MENDONÇA, Rui. O Cartaz e a Escola. 2007. Tese (Doutorado em Design) Porto. Faculdade de Belas Artes da Universidade do Porto, 2007.

MENDONÇA, Rui. Cartaz: Pensar, Desenhar, Comunicar. Porto. Modos de Ler Editores e Livreiros, 2010.

MOLES, Abraham. O Cartaz. São Paulo. Editora Perspectiva, 1974.

PELTA, Raquel. Adiós Cartel? Etapes: Diseño y Cultura Visual 12. Barcelona. Editorial Gustavo Gili, p. 52-61, 2010.

PIRES, Luis. Contributos para a actuação do SEPNA no âmbito da Educação

Ambiental. Dissertação (Mestrado em Educação Ambiental) Bragança. Escola Superior de Educação do Instituto Politécnico de Bragança, 2016.

RIBEIRO, Cristiana; MESQUITA, Cristina; RODRIGUES, Maria José; PEDRO, Rui. Advertising as a determinant of families and children's food choices. Proceedings of 11th annual International Conference of Education, Research and Innovation - ICERI 2018. Seville, p. 4495-4501, 2018.

RODRIGUES, Maria José; GONÇALVES, Adorinda. Conceções dos alunos do 1. a ano da LEB sobre as inter-relações ciência-tecnologia-sociedade. III Encontro Internacional de Formação na Docência (INCTE): livro de atas. Instituto Politécnico de Bragança. Bragança, p. 142-150, 2018.

SPÍNOLA, Helder. Forty years of environmental education in the Portuguese Democracy. The Online Journal of New Horizons in Education, 4 (3), p.47-55, 2014.

SPÍNOLA, Helder. A Literacia Ambiental numa Escola sem Muros. In FRAGA, Nuno Silva; KOT-KOTTECKI, Ana França. (org.). A Escola Restante. Funchal. CIE-UMa. p. 132-145, 2015.

SPÍNOLA, Helder. Literacia Ambiental: Um desafio à Didática e à Matética. The Online Journal of New Horizons in Education, 4 (3), p. 289-298, 2016.

TIMMERS, Margaret. The power of the Poster. Londres. V\&A Publications, 2003.

UNESCO. Environmental education in the light of Tbilisi conference. Paris. United Nations, 1980.

Rev. Eletrônica Mestr. Educ. Ambient. Rio Grande. v. 36, n. 3. Seção especial: V Congresso Internacional de Educação Ambiental dos Países e Comunidades de Língua Portuguesa. p. 319-335. Set/Dez. 2019. E-ISSN 1517-1256 